\title{
EFFECTIVENESS OF THE NEWBORN BEHAVIORAL OBSERVATION (NBO) SYSTEM IN IMPROVING MOTHER AND INFANT INTERACTION
}

\author{
Siti Wahyu Windarti ${ }^{1}$, Ahmad Suryawan ${ }^{1}$ \\ ${ }^{1}$ Department of Child Health, Faculty of Medicine, Universitas Airlangga, Surabaya, Indonesia/Dr. Soetomo \\ General Academic Hospital, Surabaya, Indonesia
}

\begin{abstract}
The interaction of mother and infant is a fundamental for the development of the infant and determine the success of the baby in the future. About 4 out of 10 infants experience problems interacting with their parents. The NBO system was created to sensitize parents to their infant's competencies, to helping them understand their infant's behavior and promote positive interactions between parents and their new infant. This study aimed to evaluate effectiveness of the NBO system in improving mother-infant interactions and to find out the mothers' knowledge about their infant's behavior when participating in this observation. This study was a cross-sectional study consisting of all the newborns and their mothers admitted to the Dr. Soetomo General Academic Hospital Surabaya in May 2019 to January 2020 who met the inclusion criteria. Mothers and infants participated in the NBO within 1-3 days after delivering their infants and 1 month postpartum for the second NBO. The $N B O$ was carried out with 35 mothers and infants. The mothers' age was on average $28.5 \pm 5.98$ years old, multiparous mothers accounted for $71.4 \%$, most infants were male (65.7\%), the median gestational age were 38 weeks with the median birth weight 2900 grams. The median score of mothers' knowledges about their infants before the NBO session was 2 (1-6). After the session, these median scores increased to 7 (5-10) significantly $(p<0.001)$. The NBO system was useful to strengthen motherinfant interaction, and increased the mothers' knowledge about their infants' behavior.
\end{abstract}

Keywords: NBO; mother; infant; mother-infant interactions

\section{ABSTRAK}

Interaksi ibu dan bayi merupakan hal yang fundamental untuk perkembangan bayi dan menentukan keberhasilan bayi dikemudian hari. Sekitar 4 dari 10 bayi mengalami masalah dalam interaksi dengan orangtuanya. Sistem Newborn Behavioral Observation (NBO) dimaksudkan agar orangtua peka terhadap perilaku dan kompetensi bayinya, sehingga memperkuat hubungan yang positif antara orang tua dan bayi. Penelitian ini bertujuan untuk mengevaluasi efektivitas sistem NBO dalam meningkatkan interaksi ibu - bayi dan untuk mengetahui pengetahuan ibu tentang perilaku bayinya ketika berpartisipasi dalam pengamatan ini. Studi ini bersifat cross-sectional dengan subyek terdiri atas semua bayi baru lahir dan ibu yang dirawat di Rumah Sakit Dr. Soetomo Surabaya antara Mei 2019 hingga Januari 2020 yang memenuhi kriteria inklusi. Ibu dan bayi akan berpartisipasi dalam NBO antara 1-3 hari setelah melahirkan dan 1 bulan setelah melahirkan untuk NBO yang kedua. NBO dilakukan pada 35 ibu dan bayi. Usia ibu rata-rata adalah 28,51+5,98 tahun, ibu multipara sebesar 71,4\%, sebagian besar bayi terdiri atas 65,7\% laki-laki, dan rata-rata usia kehamilan adalah 38 minggu dengan berat lahir rata-rata 2900 gram. Skor median pengetahuan ibu tentang bayi mereka sebelum sesi NBO adalah 2 (1-6). Setelah sesi, skor median meningkat menjadi 7 (5-10) secara signifikan ( $p<0,001)$. Sistem NBO berguna untuk memperkuat interaksi ibu-bayi dan meningkatkan pengetahuan ibu tentang perilaku bayi mereka.

Kata kunci: NBO; ibu; bayi; interaksi ibu-bayi

Correspondence: Ahmad Suryawan, Department of Child Health, Faculty of Medicine, Universitas Airlangga / Dr. Soetomo General Academic Hospital, Surabaya, Indonesia. Email: ahmad.suryawan@fk.unair.ac.id

pISSN:2355-8393 • eISSN: 2599-056x • doi: 10.20473/fmi.v57i2.21558

- Fol Med Indones. 2021;57:90-94 • Received 24 Aug $2020 \bullet$ Accepted 12 Nov 2020

- Open access under CC-BY-NC-SA license • Available at https://e-journal.unair.ac.id/FMI/ 


\section{INTRODUCTION}

Mother and infant interaction is sufficiently important for the development of the baby, and to determine the success of the baby in the future. About 4 out of 10 babies experience problems interacting with their parents (Chiu \& Cranston 2009, Moullin et al 2014). This can occur, because mother's behavior, behavior of the infant, and relationship of mother and infant that are not appropriate, and ultimately can affect the quality of their interaction (Wendland-carro et al 1999). Relationships developed between infant and their mother in any time can have long-term effects on infant's cognition, emotion, and social development. Sensitivity to infant cues and communication is an important component in strengthening mother and infant interaction. This evidence does not only involve the ability to understand and interpret infant cues accurately, but also provide some appropriate and timely responses (Hawthorne \& Savage 2013).

The Newborn Behavioral Observations (NBO) is a system used to observe infant behavior, to describe the competence and individuality of a newborn. The NBO system was created to sensitize parents to their infant's competencies as well as to help them understand their infant's behavior, and thereby promoting positive interactions between parents and their new infant and contribute to development of a positive parent-infant relationship (Nugent et al 2016). Some studies on NBO showed that the NBO system could help parents to understand their infant's behavior better, contributed to strengthen relationship and interaction between mothers and newborns, be more confident as a mother as well as reducing maternal depression (Mcmanus \& Nugent 2012, Nugent et al 2014).

This study was to evaluate the effectiveness of the Newborn Behavioral Observation (NBO) system in improving mother - infant interaction, and to find out the mothers' knowledge about their infant's behavior when participating in this observation.

\section{MATERIALS AND METHODS}

This study was a cross-sectional study that analyzed the behavior of newborns using the NBO. The convenience sample consisted of all the newborns and their mothers admitted to Dr. Soetomo General Academic Hospital Surabaya in the period of May 2019 to January 2020 who agreed to participate in the study. Mother and infant identified eligible on the basis of the following criteria: mothers had no perinatal complications, the infants were all between 37-41 weeks of gestational age with birth weights above $2500 \mathrm{~g}$, the Apgar scores were no less than 7 at 5 minutes and 9 at 10 minutes, had no congenital anomalies and no use of the neonatal intensive care unit. During data collection, there were 167 mothers and 130 term infants were excluded due to birth weight less than $2500 \mathrm{~g}$, congenital anomalies, early-onset sepsis (EOS) and respiratory distress. A total of 37 mothers and infants met the inclusion participated in the NBO. At 1 months postpartum, 35 mother-infant made up the final sample. Two mothers could not be contacted. Mothers and infants would receive routine hospital care and participated in the NBO within 1-3 days after delivering their baby and 1 month postpartum for the second NBO.

The NBO consisted of 18 behavioral and reflex items divided into four dimensions represented by the acronym AMOR: (A) autonomic system consisting of skin color, respiratory pattern, visceral function; (M) motor system consisting of tonus of arms, legs, shoulder and neck, activity level, and sucking, rooting, and hand grasping reflexes; $(\mathrm{O})$ organization of alertness states consisting of capacity for habituation and sleep preservation, crying, consolability, and transition between alertness states; and (R) responsiveness consisting of ability to respond and interact with people and objects with visual and auditory stimuli. All items were scored on a three-point scale, with one point being assigned to weak (weak neck tonus, for instance) or altered responses (e.g., very intense stress signals), two points to transition behaviors, and three to wellestablished behaviors (e.g., easy habituation to light and sound) (Nugent et al 2016).

The observation was made with the use of a rattle, a red ball, and a flashlight; the procedure carried out in approximately 10 minutes and performed up to the corrected age of three months (Nugent et al 2016). The NBO was performed with one dyad at a time in the room where they were admitted between feedings. The sleep and wakefulness states were evaluated at the beginning of the observation based on the criteria established by the NBO authors. The procedures for habituation to light and sounds were performed only when infant was in a light or deep sleep (Fishman et al 2007).

The NBO also included a questionnaire for parents, to which they assessed the effectiveness of the NBO in helping them understand their baby's behavior (McManus 2015). This questionnaire was divided into two parts, namely (1) the first three questions addressed parental knowledge on neonatal behavior, and (2) other three questions addressed the experience with the NBO session. The items were scored on a four-point Likert scales, namely "a lot", "enough", little", and "nothing". The questions that addressed parents' knowledge about 
their infants' behavior before and after the NBO were scored on a scale of " 1 "' (little) to " 10 ", (a lot) (Nugent et al 2016).

As described in the NBO manual, the professionals started the session by explaining mothers that the NBO was not a diagnostic test and it did not identify pathological or atypical signs, but it was an approach based on newborn's skills. It was an observation used to help parents recognize the behaviors and identified the caring strategies fit to their infants' needs (Nugent et al 2016). The mothers were invited to participate as partners in the observation. During the session, the professionals praised their previous knowledge and allowed them to clarify doubts and expressed their concerns. At the end of the session, they (professionals and mothers) discussed the observed behaviors, identifying strengths and areas where the newborn needed a support. Then, the mothers answered the questionnaire assessing her experience during the session.

All data were tested for normality with the Kolmogorov-Smirnov test. When the data were normally distributed, a mean (SD) would be obtained. Yet, when the data were not normally distributed, a median (range) would be obtained. Comparison of the perception of mothers about their knowledge on infants' behavior before and after NBO session was carried out by using Wilcoxon test with a significance value of $\mathrm{p}$ $<0.05$.

\section{RESULTS}

The NBO was carried out with 35 mothers and infants. The characteristics of mothers and infants are shown in Table 1. The mothers' age had on average $28.51 \pm 5.98$ years old, multiparous mothers accounted for $71.4 \%$, and a half of mothers $(51.1 \%)$ were unemployed. Most infants $(65.7 \%)$ were male, the median gestational age were 38 weeks with the median birth weight 2900 grams.

Table 1. Baseline characteristic of mothers and infants

\begin{tabular}{ll}
\hline Characteristic of mothers & \\
\hline Age, years (mean \pm SD) & $17-40(28.51$ \\
Parity, n (\%) & $\pm 5.98)$ \\
$\bullet \quad 1$ & $10(28.6)$ \\
$\bullet \quad 2$ & $12(34.3)$ \\
$\bullet \quad \geq 3$ & $13(37.1)$ \\
Employment, n (\%) & $17(48.6)$ \\
$\bullet \quad$ Part-time & $18(51.4)$ \\
$\bullet \quad$ Unemployed & $1(2.9)$ \\
Last Education, n (\%) & $6(17.1)$ \\
$\bullet \quad$ Elementary school & $15(42.9)$ \\
$\bullet \quad$ Middle school & $13(37.1)$ \\
$\bullet \quad$ High school & \\
$\bullet \quad$ College & $23(65.7)$ \\
\hline Characteristic of infants & $12(34.3)$ \\
\hline Gender, n (\%) & $38(37-40)$ \\
$\bullet \quad$ Male & $2900(2500-$ \\
Gestational age, weeks (range) & $3500)$ \\
Birth weight, gram (range) & \\
\hline $\mathrm{n}$, sample size; SD, standard deviation
\end{tabular}

n, sample size; $\mathrm{SD}$, standard deviation

Table 2. Analysis of the mothers' perception of the Newborn Behavioral Observation (NBO) session's contribution to the relationship with their babies and with healthcare professionals

\begin{tabular}{|c|c|}
\hline Parents' Questionnaire & $\begin{array}{c}\mathrm{n}=35 \\
\text { Median (range) }\end{array}$ \\
\hline $\begin{array}{l}\text { During the observation session, how much did you learn about: } \\
\text { - your infant's skills (What is he/she able to do now)? }{ }^{\mathrm{a}} \\
\text { - how can your infant communicate with you through behavior? } \\
\text { - how you can respond to your baby's behavior? }{ }^{\mathrm{a}} \\
\text { - how you can help your baby when he/she is crying? } \\
\text { - how to interact with your infant? }\end{array}$ & $\begin{array}{l}2(1-2) \\
1(1-3) \\
2(1-3) \\
1(1-2) \\
2(1-2)\end{array}$ \\
\hline $\begin{array}{l}\text { Overall, how much would you say the NBO helped you: } \\
\text { - to feel closer to your infant? } \\
\text { - to feel more confident as a parent? } \\
\text { - to get to know your baby better? } \\
\text { - to communicate and connect with the person who conducted the } \\
\text { observation? } \\
\text { How do you assess the NBO session as a learning experience? }\end{array}$ & $\begin{array}{l}4(2-4) \\
4(2-4) \\
4(2-4) \\
4(2-4) \\
3(3-4)\end{array}$ \\
\hline
\end{tabular}




\footnotetext{
${ }^{\text {a }}$ Questions answered on a 4-point Likert scale, with 1 corresponding to a lot; 2, enough; 3, little; 4, nothing.

${ }^{\mathrm{b}}$ Questions answered on a 4-point Likert scale, with 1corresponding to very little; 2 , a little; 3, enough; 4, a lot.

${ }^{\mathrm{c}}$ Questions answered on a 4-point Likert scale, with 1 corresponding to weak; 2, fair; 3, good; 4, excellent.
}

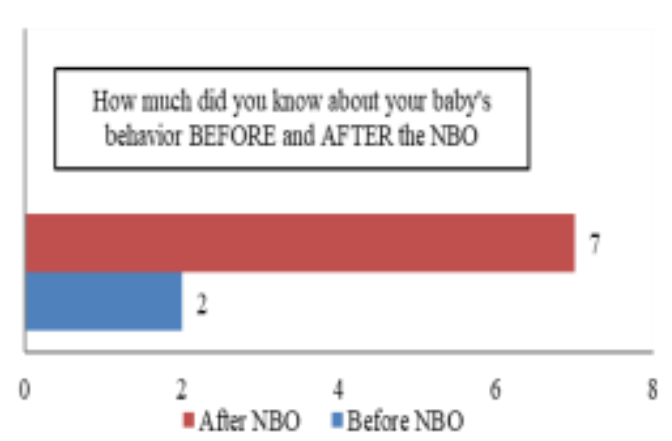

Figure 1. Analysis of the mothers' perception of their knowledge about their baby's behavior before and after the newborn behavioral observation (NBO) session

Table 2 showed the answers of mothers to the questions in the parents' questionnaire during the NBO sessions. The mothers reported that the NBO helped them "a lot/"enough" to feel more confident as mothers and to know their infants better, to feel closer to their infants, to learn about their infant's abilities, how to respond and interact with their infants, and how infants communicated through behavior.

Figure 1 showed a comparative analysis of the perception of mothers about their knowledge on infants' behavior before and after the NBO session. On a scale of $0-10$, the median score attributed to the knowledge prior to the session was $2(1-6)$. After the NBO session, these median scores increased to $7(5-10)$ significantly $(\mathrm{p}<0.001)$

\section{DISCUSSION}

Thirty-five mothers with healthy babies were interviewed about their experience during NBO sessions. They described that a feeling of confidence, learning about their infants, being able to know their infants' needs, and pleasure of interacting with their infants at an early stage were all significances in the transition to motherhood. Most of them would explore their infants, finding out solutions, and organizing their interaction with their infants regardless of whether they were familiar with the NBO system or not. However, the NBO seemed to help revealing the infants' abilities in the early postpartum period, and their mothers and fathers were surprised at their discovery.

The results of this study indicated that the NBO system might be an effective intervention for healthcare professional to conduct a collaboration with mothers to build positive relationships with their newborns. As hypothesized, we found some effects of the NBO on the quality of mother-infant interaction. The NBO was an observation system designed to describe newborn's abilities and individuality, to foster the relationship between parents and their infants, and to promote the development of a supportive relationship between family and the professionals (Nugent et al 2016, Gibbs 2015). The mothers who participated in the NBO session improved positive relationship between parents and their newborns than the control group which received usual early intervention care (McManus \& Nugent 2012).

The approach proposed by the NBO was well appraised by mothers-in charge and represented a significant knowledge on their infants' behavior in this study. The mothers reported lower baseline knowledge than that reported by Guimaraes et al (2017). A similar finding was observed in another study, where maternal reports indicated that the NBO was effective in increasing knowledge about behavior and how to respond and interact with their newborns (Sanders \& Buckner 2006). Cheetham et al (2014) observed an increase in maternal sense of competence and confidence when facing the challenges of motherhood; considering that the NBO as a strategic resource to improve the transition to motherhood, to provide support in early family life, and as postpartum support. Kashiwabara (2013) concluded that the NBO provided an opportunity for parents to know their children better and to establish closer ties with them.

\section{CONCLUSION}

The NBO system was useful to strengthen mother-infant interaction, and increased mothers' knowledge on their infants' behavior.

\section{ACKNOWLEDGMENT}

Thanks to Rudi who helped to record videos on mothers and babies that participated in the NBO session.

\section{REFERENCES}

Cheetham NB, Hanssen TA, Tove A (2014). The neonatal behavioral observation system: A tool to 
enhance the transition to motherhood. Nordic J Nurs Research 4, 48-52.

Chiu S, Cranston G (2009). Effect of early skin-to-skin contact on mother-preterm infant interaction through 18 months: Randomized controlled trial. Intern J Nurs Stud 46, 1168-180.

Fishman J, Vele-Tabaddor E, Blanchard Y, et al (2007). The effect of the NBO on caregiver relationships. Ab Initio Intern Onl J. Available from http://www.brazelton-

institute.com/abinitio2007summer/art2.html. Accessed March 11, 2019.

Gibbs DP (2015). Supporting the parent-infant relationship: using the neonatal behavioural observation in the neonatal intensive care unit. APCP J 6, 26-34.

Guimaraes MAP, Alves CRL, Cardoso AA, et al (2017). Clinical application of the Newborn Behavioral Observation (NBO) system to characterize the behavioral pattern of newborns at biological and social risk. J Pediatr 94, 1-8.

Hawthorne J, Savage E (2013). Newborn behavioural observation: Helping new fathers and their babies. Available from https://www.nct.org.uk/sites. Accessed October 18, 2018

Kashiwabara E (2013). Effectiveness of the NBO with Japanese parents with breastfeeding difficulties. Ab Initio Intern. Available from: http://www.childrenshospital.org/centers-andservices/ab-initio-international-program/effectivenessof-the-nbo-with-japanese-parents with-breastfeedingdifficulties. Accessed July 21, 2019
McManus BM (2015). Integration of the newborn behavioral observation (NBO) system into care settings for high-risk newborns. Zero Three 36, 11-20.

Mcmanus BM, Nugent JK (2012). A neurobehavioral intervention incorporated into a state early intervention program is associated with higher perceived quality of care among parents of high-risk newborns. J Behav Health Serv Res 41, 1-8.

Moullin S, Waldfogel J, Washbrook E (2014). Baby bonds parenting, attachment and a secure base for children. Available from https://scholar.princeton.edu/ smoullin/publications/baby-bonds-parentingattachment-and-secure-base-children. Accessed October 18, 2018

Nugent JK, Bartlett JD, Valim C (2014). Effects of infant-focosed relationship-based hospital and home visiting intervention on reducing symptoms of postpartum maternal depression. Inf Young Child 4, 92-304.

Nugent JK, Keefer HC, Minear S, et al (2016). Understanding newborn behavior and early relationship: the newborn behavioral observations (NBO) system handbook: 7th ed, Baltimore, Brookes Publishing Co.

Sanders LW, Buckner EB (2006). The newborn behavioral observations system as a nursing intervention to enhance engagement in first-time mothers: feasibility and desirability. Pediatr Nurs 32, 455-9.

Wendland-carro J, Piccinini CA, Millar WS (1999). The role of an early intervention on enhancing the quality of mother-infant interaction. Child Develop 70, 71321. 